\title{
Investigation of the effect of some plant aqueous extracts on calcium phosphate precipitation as a simulation of initial dental calculus formation in vitro
}

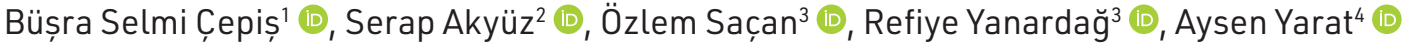 \\ 'Marmara University, Faculty of Pharmacy, Health Sciences Institutes, Department of Biochemistry, Istanbul, Turkey \\ ${ }^{2}$ Marmara University, Faculty of Dentistry, Department of Clinical Sciences Pedodontics), Istanbul, Turkey \\ ${ }^{3}$ Istanbul University-Cerrahpasa, Faculty of Engineering, Department of Chemistry (Biochemistry), Istanbul, Turkey \\ ${ }^{4}$ Marmara University, Faculty of Dentistry, Department of Basic Medical Sciences (Biochemistry), Istanbul, Turkey
}

ORCID IDs of the authors: B.S.C. 0000-0002-6198-2218; S.A. 0000-0002-1358-0150; 0̈.S. 0000-0001-6503-4613; R.Y. 0000-0003-4185-4363; A.Y. 0000-0002-8258-6118

Cite this article as: Selmi Cepis, B., Akyuz, S., Sacan, O., Yanardag, R., \& Yarat, A. (2020). Investigation of the effect of some plant aqueous extracts on calcium phosphate precipitation as a simulation of initial dental calculus formation in vitro. Istanbul Journal of Pharmacy, 50 (3), 262-267.

\begin{abstract}
Background and Aims: Calcium phosphate is most of the inorganic content of dental calculus. Therefore, knowing or controlling the precipitation mechanism of calcium phosphate is very important for the inhibition of dental calculus formation at the beginning. Plants have been known to be excellent sources of many nutritional and phytochemical content. The aim of this study is to investigate the effects of Petroselinum crispum, Eruca vesicaria ssp. sativa, Beta vulgaris L.var. cicla, Rumex cristatus DC. and Cotinus coggygria Scop. aqueous extracts on calcium phosphate precipitation, which is thought to reflect the onset of dental calculus formation in vitro.

Methods: The optical density (OD) increases first with the calcium phosphate nucleation and when the balance is reached, the optical density decreases gradually when the nuclei begin to aggregate and precipitate. The OD change was monitored by recording the absorbance at $620 \mathrm{~nm}$.

Results: The effect on the calcium phosphate precipitation varied differently among the 5 types of aqueous extracts. The smoke tree (Cotinus coggygria Scop.) extract activated calcium phosphate precipitation while all others inhibited precipitation. Conclusion: These results suggest that some types of plant aqueous extracts may have protective potential against dental calculus initially and, therefore they may be used in toothpastes or in mouthwashes.
\end{abstract}

Keywords: Dental calculus, calcium phosphate precipitation, plant aqueous extract

\section{INTRODUCTION}

Among oral and dental health problems, dental calculus has an increasing prevalence due to changes in the diet and nutritional habits of societies (Akar, 2014) and causes many oral problems, such as noneaesthetic appearance and bad breath. Although dental calculus is not directly responsible for the occurrence of health problems such as diabetes, urinary stone formation, and cardiovascular disease, it is a secondary factor in disease progression (Batool et al., 2018, Clarke, 2015).

Dental calculus is a mineralized bacterial plaque which is a hard and calcified deposit with a bacterial plaque layer clustered on natural teeth and restorations (Moolya et al., 2010). It is composed of various inorganic components, mainly calcium phosphate 
compound, and organic matrix (Jin \& Yip, 2002; White, 1997). Many factors such as diet, especially alkaline foods and sugars, saliva $\mathrm{pH}$, composition and bacterial load, age, sex, race, gender, tobacco use, presence of systemic diseases, drugs used, oral hygiene practices and socioeconomic status affect dental calculus formation (Akçalı \& Lang, 2018). Bacterial endotoxins damage the gum and periodontal tissue (Hidaka, Nishimura, Nakajima, \& Liu, 1996). Knowing and controlling the factors affecting calcium phosphate precipitation is very important for the inhibition of initial dental calculus formation (Tarasevich, Chusuei, \& Alloro, 2003). The use of plants has also become widespread in dental and oral health, with secondary metabolites and a wide range of biological activities (Gulfraz, Sadıq, Tarıq, Imran, \& Qureshi, 2011).

Petroselinum crispum (parsley, Apiaceae) has an antihistaminic, antiseptic, hepatogenic, hypotensive, and plasma calciumenhancing effect (Hazim, Al-Daraji, Al-Mashadani, Al-Hassani, \& Mirza, 2012). It contains high amounts of apigenin, ascorbic acid, eugenol, carotenoids, flavonoids, coumarins, phenylpropanoids, phthalates, furano coumarins and tocopherol components (Ajmera, Kalani, \& Sharma, 2019; Pápay, KállaiSzabó, Ludányi, Klebovich, \& Antal, 2016; Tunali et al., 1999). Eruca vesicaria ssp. sativa (garden rocket) belongs to the cabbage Brassicaceae family. It is known as a diuretic, antiulcer, antithrombotic, antioxidant, anticancer, antiplatelet and antiinflammatory (Taviano et al., 2018 and 2017; Gulfraz et al., 2011; Sacan, Orak, \& Yanardag, 2008). It contains important secondary metabolites such as flavonoids, alkaloids, tannins, phenols, saponins and ascorbic acid. Its essential oils contain high concentrations of an especially antibacterially effective erucic acid (Sarwar Alam, Kaur, Jabbar, Javed, \& Athar, 2007). Beta vulgaris L. var.cicla (chard) is from the family Chenopodiaceae and is a vegetable rich in vitamins $A, B, C$, calcium, iron, and phosphorus. In its structure, it contains fatty acids such as palmitic acid, citric acid, oleic acid, linoleic acid, and phospholipids, glycolipids, polysaccharides, saponin, pectin, and flavonoids (Tunali, 2020; Mzoughi et al., 2019). It has antidiabetic, antioxidant, antitumor, antimicrobial, hepatoprotective, antiseptic, and anti-acetylcholinesterase activity (Sacan \& Yanardag, 2010; Bolkent, Yanardağ, Tabakoğlu-Oğuz, \& Ozsoy-Saçan, 2000; Mzoughi et al., 2019). Rumex crispus (curled dock) Polygonaceae is a plant rich in anthracene derivatives from the blackgrain family. It also contains tannins, flavonoids, and naphthalene derivatives. It has antioxidant and antimicrobial effects (Idris, Wintola, \& Afolayan, 2019; Demir, Bozkurt, Onur, Kay, \& Somer, 2017; Coruh, Gormez, Ercisli, \& Sengul, 2008). Cotinus coggygria (smoke tree) is a plant belonging to the Anacardiaceae family, generally known as "smoke tree". It has been shown by in vivo and in vitro studies that it has many activities such as antioxidant, antibacterial, antifungal, antiviral, hepatoprotective, and anti-inflammatory (Matić, Stanić, Mihailović, \& Bogojević, 2016). It has been reported that the Cotinus coggygria, which has a high flavonoid content, has cytotoxic effects on bacteria and shows inhibitory properties against the common components of the dental plaque, S. mutans and S. sanguinis (Ferrazzano et al., 2013; Wang, Wang, Du, Fei, \& To, 2016).
In this study, the effects of five plant aqueous extracts (Petroselinum crispum, Eruca vesicaria ssp. sativa, Beta vulgaris L.var.cicla, Rumex cristatus DC. and Cotinus coggygria Scop.) on the mechanism of nucleation and aggregation of calcium phosphate precipitation which is thought to reflect initial dental calculus formation in vitro, was evaluated.

\section{MATERIALS AND METHODS}

\section{Preparation of plant aqueous extracts}

Plant extracts were prepared at the Department of Chemistry, Faculty of Engineering, Istanbul University-Cerrahpasa. Petroselinum crispum, Beta vulgaris L.var.cicla were identified by Prof. Dr.Neriman Ozhatay. Rumex cristatus DC., and Eruca sativa were identified by Prof. Dr. Kerim Alpinar. Cotinus coggygria was identified by Prof. Dr. Sukran Kultur, Faculty of Pharmacy, Istanbul University. The plant materials were washed with water and dried at room temperature. The dried plants were stored at $-20^{\circ} \mathrm{C}$ until used. Dried leaves (50 g) were extracted by adding $500 \mathrm{~mL}$ of distilled water and boiling for 8 hours. The extracts were then filtered and lyophilized. Then, were kept at $-20^{\circ} \mathrm{C}$. When used, the extracts were dissolved in distilled water to obtain a saturated solution.

\section{Screening of calcium phosphate precipitation}

To obtain the standard curve for nucleation and aggregation of calcium phosphate precipitates were obtained by recording the change in optical density at $620 \mathrm{~nm}$ at twominute intervals for approximately 30 minutes using the RT-9000 Semi-auto Chemistry Analyzer instrument, after mixing equal volumes of calcium chloride dihydrate (4 mM) and trisodium phosphate $(10 \mathrm{mM})$ solutions at $37^{\circ} \mathrm{C}$. Final concentrations of calcium and phosphate ions were about $2 \mathrm{mM}$ and $5 \mathrm{mM}$ respectively. They are between physiological salivary concentrations. The optical density increases first with the calcium phosphate nucleation, when the balance is reached, the optical density decreases gradually when the nuclei begin to aggregate and precipitate (Selmi Cepis, Akyuz, \& Yarat, 2020).

The effects of plant aqueous extract on calcium phosphate precipitation were examined by the addition of $50 \mu \mathrm{L}$ of an aqueous extract into the mixture of calcium and phosphate ions. Each sample was studied five times. At the end of the experiment, charts drawn between time and optical density (absorbance) and the effects of each aqueous extract on calcium phosphate precipitation were evaluated statistically.

\section{Statistics}

The Statistical Program for the Social Sciences (SPSS) (16.0, Windows) was used in the statistical evaluation of the data obtained as a result of the study and $p<0.05$ was considered statistically significant. The consistency of continuous variables to normal distribution was investigated using the KolmogorovSmirnov test. Student's t test was used in two independent group comparisons for normally distributed variables. Mann Whitney $U$ test was used in comparison of two independent groups for non-normally distributed variables. Values are given as mean \pm standard deviation (SD). 


\section{RESULTS}

The standard curve for precipitation of calcium phosphate: Time-course measurements of optic density obtained by $2 \mathrm{mM}$ of calcium and $5 \mathrm{mM}$ of phosphate solutions at 620 $\mathrm{nm}$ were illustrated in Figure 1 (Selmi Cepis, Akyuz, \& Yarat, 2020).

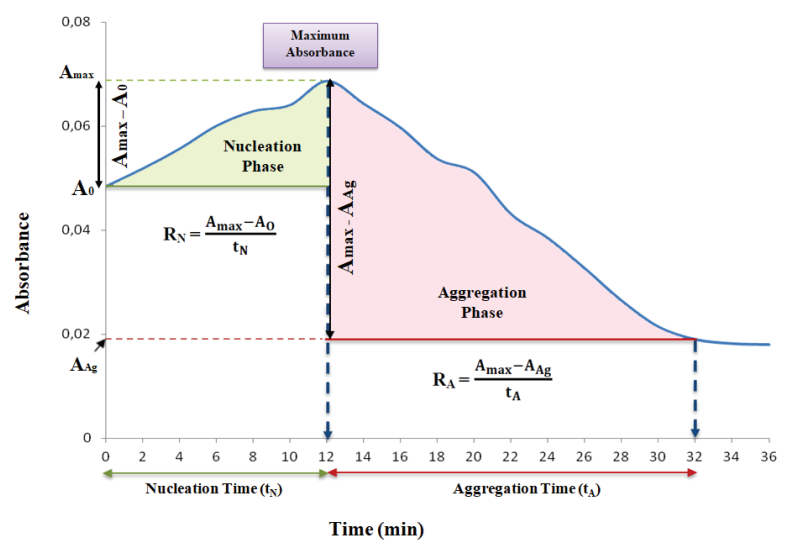

Figure 1. The standard curve for nucleation and aggregation phases of the formation of calcium phosphate precipitate (Selmi Cepis, Akyuz, \& Yarat, 2020). After mixing the calcium and phosphate solutions, the increase in optical density over time reflects the rate of formation of new nuclei and the increase in the number of calcium phosphate nuclei. When the optical density reaches the maximum value, the formation of calcium phosphate nuclei is complete. This phase is called the nucleation phase. Nucleation rate $\left(R_{N}\right)$ is the ratio of the difference between the maximum absorbance value and the original absorbance value to the time taken to reach the maximum absorbance value $\left(t_{N}\right)$. Optical density decreases gradually over time. The decrease in the optical density reflects the reduction of the number of nuclei dispersed in the solution due to the aggregation of calcium phosphate nucleis. This is called the aggregation phase. $R_{A}$ is the ratio of difference between the maximum absorbance value and the absorbance value where the optical density no longer decreases to the time taken to decrease the maximum absorbance $\left(t_{A}\right)$.
Effects of plants aqueous extracts in calcium phosphate precipitation: The effects of Petroselinum crispum, Eruca vesicaria ssp. sativa, Beta vulgaris L.var.cicla, Rumex cristatus DC. and Cotinus coggygria Scop. aqueous extracts are shown in the Figure 2. Compared to a standard curve, all extracts except Cotinus coggygria prolonged nucleation time, decarsed the nucleation rate significantly. Cotinus coggygria and Rumex crispus. shorthened aggregation time significantly. All extracts increased aggregation rate significantly compared to a standard curve. The increase in the aggregation rate for Cotinus coggygria was significantly more than those of other extracts (Table 1 and Figure 2).

\section{DISCUSSION}

Physiologically, normal $\mathrm{Ca}^{2+}$ ion concentration in saliva has been reported to be 1.03-3.6 $\mathrm{mM}$ and $\mathrm{PO}_{4}{ }^{3-}$ ion concentration 4.5-6 $\mathrm{mM}$. Any imbalance in these concentrations bring various problems in terms of dental and oral health. The most important of these is dental calculus formation. Calcium phosphate supersaturation, which is realized by increasing the concentration of $\mathrm{Ca}^{2+}$ and $\mathrm{PO}_{4}{ }^{3-}$ ions in saliva, is a thermodynamic driving factor for dental calculus formation (Morta, Mante, Rasa, \& Gintaras, 2018). Therefore, to obtain a standard curve, which nucleation and aggregation phases of calcium phosphate precipitation can be monitored in a short time interval and in a good manner, preliminary experiments were carried out with different concentrations of these two ions. As a result, for final concentration in the mixture, $2 \mathrm{mM}$ calcium and $5 \mathrm{mM}$ phosphate ion concentrations, which are in the interval of salivary physiologic concentaration, were found suitable to obtain a standard curve of calcium phosphate precipitation. To examine the effect of plant aqueous extracts, this standard curve was used for comparison in the present study.

In their study, Hidaka \& Oishi (2007), examined the effect of nutritional components on dental calculus formation, and used both calcium and phosphate ion final concentrations of $3 \mathrm{mM}$,

Table 1. The effects of plant aqueous extracts on the nucleation and aggregation phases of calcium phosphate precipitation.

\begin{tabular}{|c|c|c|c|c|c|c|}
\hline & $\begin{array}{l}\text { Standard } \\
\text { (Calsium } \\
\text { phospathe } \\
\text { without extracts) }\end{array}$ & $\begin{array}{l}\text { Petroselinium } \\
\text { crispum }\end{array}$ & $\begin{array}{l}\text { Eruca } \\
\text { vesicaria ssp. } \\
\text { Sativa }\end{array}$ & $\begin{array}{l}\text { Beta vulgaris } \\
\text { L. Var. Cicla }\end{array}$ & $\begin{array}{c}\text { Rumex } \\
\text { cristatus DC. }\end{array}$ & $\begin{array}{l}\text { Cotinus } \\
\text { coggygria } \\
\text { Scop. }\end{array}$ \\
\hline $\begin{array}{l}\text { Nucleation rate } \\
\left(\mathrm{R}_{\mathrm{N}}\right)\left(\times 10^{-3} / \mathrm{min}\right)\end{array}$ & $1.66 \pm 0.69$ & $1.42 \pm 0.29$ & $1.04 \pm 0.11$ & $1.36 \pm 0.61$ & $1,10 \pm 0,71$ & $3,14 \pm 0,89^{* \# \# \mathrm{~b}}$ \\
\hline $\begin{array}{l}\text { Aggregation } \\
\text { rate (RA) }\left(\times 10^{-3 /}\right. \\
\min )\end{array}$ & $2.68 \pm 0.35$ & $3.36 \pm 0.38^{* a}$ & $3.90 \pm 0.83^{* a}$ & $0.72 \pm 0,25^{\star \star b}$ & $3,92 \pm 0,29^{\star * b}$ & $5,46 \pm 1,34^{* \star \# \# \mathrm{~b}}$ \\
\hline $\begin{array}{l}\text { Nucleation time } \\
\left(t_{N}\right)(\min )\end{array}$ & $12.80 \pm 1.78$ & $40.0 \pm 4.24^{* *_{b}}$ & $60.0 \pm 3.16^{* \star_{\varepsilon \varepsilon b}}$ & $17,20 \pm 3,03^{* a}$ & $37,6 \pm 0,89^{* * \mathrm{~b}}$ & $12,40 \pm 1,67$ \\
\hline $\begin{array}{l}\text { Aggregation } \\
\text { time }\left(t_{A}\right)(\min )\end{array}$ & $21.20 \pm 2.04$ & $22.40 \pm 3.20$ & $20.40 \pm 2.94$ & $25,60 \pm 3,44$ & $14,4 \pm 0,80^{* *_{b}}$ & $17,60 \pm 1,49^{*}$ \\
\hline \multicolumn{7}{|c|}{$\begin{array}{l}\text { Values were given as mean } \pm \text { standard deviation; }{ }^{*} p<0.05,{ }^{* *} p<0.01 \text { : Significantly different from standard; }{ }^{* \#} p<0.01 \text { : Significantly different from } \\
\text { Petroselinum crispum, Eruca vesicaria ssp. sativa, Beta vulgaris L. var.cicla, Rumex crispus; }{ }^{\varepsilon \varepsilon} p<0.01 \text { : Significantly different from Petroselinum } \\
\text { crispum, Beta vulgaris L. var.cicla, Rumex crispus;. Cotinus coggygria aStudent t test, }{ }^{\circ} \text { Mann Whitney U test }\end{array}$} \\
\hline
\end{tabular}



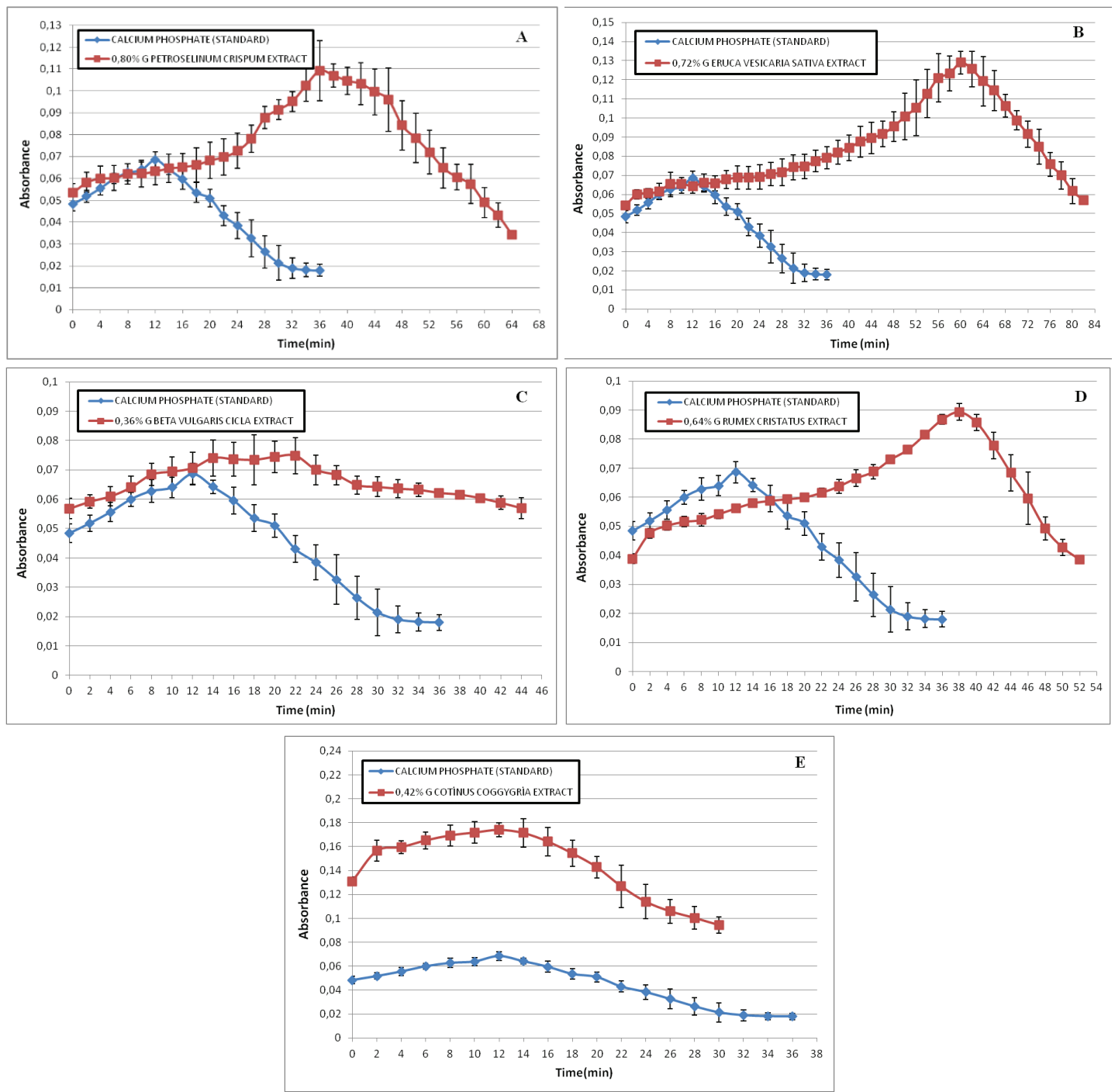

Figure 2. The effect of (A) Petroselinum crispum, (B) Eruca vesicaria ssp. sativa, (C) Beta vulgaris L. var.cicla, (D) Rumex crispus, (E) Cotinus coggygria,aqueous extracts on calcium phosphate precipitation.

unlike our study. However, the concentrations they used did not fully reflect saliva conditions.

Plant extracts have an important place in modern medicine due to their chemical and medicinal ingredients. As their metabolites have a wide range of biological activities, the use of plants has also become widespread in dental and oral health (Sener \& Kilic, 2019; Chandra Shekar et al., 2015; Gulfraz et al., 2011). It has been suggested that some plant extracts can be effective in the formation of calculus in different rates because of their phenolic components such as flavonoids, tannins, and coumarins (Ohtani \& Nishimura 2020; Ben Lagha, Dudonné, Desjardins, \& Grenier, 2015; Weber, Hannig, Pötschke, Höhne, \& Hannig, 2015; Ferrazzano et al., 2011). In studies conducted with high polyphenol content, plants have an inhibitory effect on calcium phosphate precipitation. Hidaka, Okamoto, Ishiyama, \& Hashimoto (2008) reported that propolis and honey varieties known to contain flavonoids have an inhibitory effect on calcium phosphate precipitation, and that their inhibitory effects increase with increasing flavonoid content. Similar results were obtained in studies with green tea, R. rhizoma plant, and various Kampo plants with high polyphenol content (Torki et al., 2018; Anushya \& Freeda, 2017; Hidaka et al., 1996). In the present study, Petroselinum crispum, Eruca vesicaria ssp. sativa, Beta vulgaris $L$. var.cicla and Rumex crispus were shown to inhibit calcium phosphate precipitation.

However, the Cotinus coggygria aqueous extract showed an activator effect on calcium phosphate precipitation. It has been reported that Cotinus coggygria with a high flavonoid content has cytotoxic effects on bacteria, and shows inhibitory properties against the common components of dental plaque such as S. mutans and S. sanguinis (Ferrazzano et al., 2013; Wang et al., 2016). The contrasting effect of Cotinus coggygria, rich in polyphenols and expected to prevent calcium phosphate precipitation, may have arisen from its antibacterial effects and dye components.

Moreover, polyphenols in plants have been reported to inhibit the glucosyl transferase activity of Streptococcus mutans (Veloz et al., 2016; Guven \& Erkan, 2015; Smullen, Finney, Storey, \& Foster, 2012). For this reason, polyphenols are considered as 
important substances for oral hygiene in terms of dental caries and dental calculus formations (Dash, Singh, Gupta, Panwar, \& Ramisetty, 2014). Its mechanisms of action is based on their affinity for proteins. When approached from this perspective, they bind to amylase and glycosyl transferase enzymes and they inactivate those enzymes.

\section{CONCLUSION}

The results of our study showed that Petroselinum crispum, Rumex cristatus DC, Beta vulgaris L.var.cicla, and Eruca sativa aqueous extracts can be effective at the beginning on the calcium phosphate precipitation which may reflect on dental calculus formation. In the limitations of our study, any effect of Cotinus coggygria Scop. was found on precipitation. Nevertheless, more study needs to be done. Our study is the first attempt to apply the plant aqueous extracts to the area of oral health, such as their potential effects on calcium phosphate precitation at the beginning of dental calculus formation. Furthermore our study also highlights that more plants can be examined in this way.

In our study, we examined the effects of plant extracts separately. Our aim was to determine the impact of each separately. Further studies may be done to see what kind of result can be obtained by mixing two or more of the plant extracts having synergic effects. This may be especially important in the process of producing more effective products to prevent dental calculus precipitation.

Ethics Committee Approval: Not necessary for this study.

Informed Consent: Written consent was obtained from the participants.

Peer-review: Externally peer-reviewed.

Author Contributions: Conception/Design of Study: A.Y., S.A.; Data Acquisition: B.S.Ç., A.Y.; Data Analysis/Interpretation: A.Y., B.S.Ç., S.A., Ö.S., R.Y.; Drafting Manuscript: B.S.Ç., A.Y.; Critical Revision of Manuscript: S.A., Ö.S., R.Y.; Final Approval and Accountability: A.Y., B.S.Ç., S.A., Ö.S., R.Y

Conflict of Interest: The authors have no conflict of interest to declare.

Financial Disclosure: This study was supported by Marmara University Scientific Research and Project Commision (Project No: SAG-CYLP-120619-0219).

\section{REFERENCES}

- $\quad$ Ajmera, P., Kalani, S., \& Sharma, L. (2019). Parsley-benefits and side effects on health. International Journal of Physiology, Nutrition and Physical Education 4(1), 1236-1242. http://www.journalofsports. com/pdf/2019/vol4issue1/PartAA/4-1-308-629.pdf

- Akar, C. (2014). Türkiye'de ağız-diş sağlığı hizmetlerinin strateji değerlendirmesi. Türk Diş Hekimleri Birliği Yayınları Araştırma Dizisi, 9(11),1-12. https://dergipark.org.tr/tr/download/articlefile/620472

- Akcalı, A., \& Lang, N. P. (2018). Dental calculus: the calcified biofilm and its role in disease development. Periodontology 2000, 76(1), 109-115. https://doi.org/10.1111/prd.12151

- Anushya, G., \& Freeda, T. H. (2017). Effect of green tea on the growth of brushite crystals. International Journal of Latest Trends in Engineering and Technology, (Special issue), 139-143.
Batool, H., Nadeem, A., Kashif, M., Shahzad, F., Tahir, R., \& Afzal, N. (2018). Salivary levels of IL-6 and IL-17 could be an indicator of disease severity in patients with calculus associated chronic periodontitis. BioMed Research International, 8531961. https://doi. org/10.1155/2018/8531961

- $\quad$ Ben Lagha, A., Dudonné, S., Desjardins, Y., \& Grenier, D. (2015). Wild blueberry (Vaccinium angustifolium Ait.) polyphenols target fusobacterium nucleatum and the host inflammatory response: Potential innovative molecules for treating periodontal diseases. Journal of Agricaltural Food Chemistry, 63(31), 6999-7008. doi:10.1021/acs.jafc.5b01525

- Bolkent, S., Yanardağ, R., Tabakoğlu-Oğuz, A., \& Ozsoy-Saçan, O. (2000). Effects of chard (Beta vulgaris L. var. cicla) extract on pancreatic B cells in streptozotocin-diabetic rats: a morphological and biochemical study. Journal of Ethnopharmacology, 73(1-2), 251-259. https://doi.org/10.1016/s0378-8741(00)00328-7

Chandra Shekar, B. R., Nagarajappa, R., Suma, S., \& Thakur, R. (2015). Herbal extracts in oral health care - A review of the current scenario and its future needs. Pharmacognosy Reviews, 9(18), 87-92. https://doi.org/10.4103/0973-7847.162101

- Clarke, M. R. (2015). Dental calculus: Combining current methods in the study of diet and mouth use activities among neolithic and early bronze age hunter-gatherers of the Cis-Baikal, Siberia. University of Saskatchewan. Department of Archaeology and Anthropology, Thesis Submitted to the College of Graduate Studies and Research, Saskatoon.

Coruh, I., Gormez, A., Ercisli, S., \& Sengul, M. (2008). Total phenolic content, antioxidant and antibacterial activity of Rumex crispus grown wild in Turkey. Pharmaceutical Biology, 46, 634-638. https://doi.org/10.1080/13880200802182240

- Dash, T. R., Singh, N., Gupta, D., Panwar, E., \& Ramisetty, S. (2014). Role of medicinal herbs in oral health management. International Journal of Dental and Medical Research, 1(2),113-119. http://www. ijohmr.com/upload/20.pdf

- $\quad$ Demir, S., Bozkurt, B., Onur, M. A., Kay, I. G., \& Somer, N. U. (2017). Determination of antioxidant properties of Rumex crispus and Scrophularia canina subsp.bicolor. International Journal of Secondary Metabolite, 4(3), 55-57. doi.org/10.21448/ijsm.356275

- Ferrazzano, G. F., Amato, I., Ingenito, A., Zarrelli, A., Pinto, G., \& Pollio, A. (2011). Plant polyphenols and their anti-cariogenic properties: A review. Molecules, 16, 1486-1507. doi:10.3390/molecules16021486 - Ferrazzano, G. F., Roberto, L., Catania, M. R., Chiaviello, A., De Natale, A., Roscetto, E., Pinto, G., Pollio, A., Ingenito, A., \& Palumbo, G. (2013). Screening and scoring of antimicrobial and biological activities of Italian vulnerary plants against major oral pathogenic bacteria. Evidence-Based Complementary and Alternative Medicine: eCAM, 2013, 316280. https://doi.org/10.1155/2013/316280

- Gulfraz, M., Sadıq, A., Tarıq, H., Imran, M., \& Qureshi, R. (2011) Phytochemical analysis and antibacterial activity of Eruca sativa seed. Pakistan Journal of Botanics. 43(2),1351-1359. http://www.pakbs. org/pjbot/PDFs

- Guven, A., \& Erkan, E. (2015). Fare karaciğer dokusunda yeşil çay (camellia sinensis l.) ve maydanozun (petroselinum crispum) MDA ve GSH düzeyleri üzerine etkilerinin araştırılması. Caucasian Journal of Science, 6, 65-72. https://dergipark.org.tr/tr/pub/cjo/issue/33907/382470

- Hazim, J., Al-Daraji, H. A., Al-Mashadani A. S, Al-Hassani, H. A., \& Mirza, W. K. (2012) The influence of parsley (Petroselinum crispum) as feed additive on hematological traits of local Iraqi Geese. Advances in Nutritional Research, 1(1), 1-5. https://www.iasj.net/ iasj?func $=$ fulltext\&ald $=120570$

- Hidaka, S., Nishimura, H., Nakajima, K., \& Liu, S. Y. (1996). Effects of a rhubarb (Rhei rhizoma) solution and its fractions on the formation of calcium phosphate precipitates. Journal of Periodontal Research, 31(6), 408-413. https://doi.org/10.1111/j.1600-0765.1996.tb00509.x 
- Hidaka, S., \& Oishi, A. (2007). An in vitro study of the effect of some dietary components on calculus formation: regulation of calcium phosphate precipitation. Oral Diseases, 13(3), 296-302. https:// doi.org/10.1111/j.1601-0825.2006.01283.x

- Hidaka, S., Okamoto, Y., Ishiyama, K., \& Hashimoto, K. (2008). Inhibition of the formation of oral calcium phosphate precipitates: the possible effects of certain honeybee products. Journal of Periodontal Research, 43(4), 450-458. https://doi.org/10.1111/j.16000765.2008.01088.x

- Idris, O. A., Wintola, O. A., \& Afolayan, A. J. (2019). Evaluation of the bioactivities of Rumex crispus $L$. leaves and root extracts using toxicity, antimicrobial, and antiparasitic assays. Evidence-Based cComplementary and Alternative Medicine: eCAM, 2019, 6825297. https://doi.org/10.1155/2019/6825297

- Jin, Y., \& Yip, H. K. (2002). Supragingival calculus: formation and control. Critical Reviews in Oral Biology and Medicine: an official publication of the American Association of Oral Biologists, 13(5), 426-441. https://doi.org/10.1177/154411130201300506

- Matić, S., Stanić, S., Mihailović, M., \& Bogojević, D. (2016). Cotinus coggygria Scop.: An overview of its chemical constituents, pharmacological and toxicological potential. Saudi Journal of Biological Sciences, 23(4), 452-461. https://doi.org/10.1016/j. sjbs.2015.05.012

- Moolya, N. N., Thakur, S., Ravindra, S., Setty, S. B., Kulkarni, R., \& Hallikeri, K. (2010). Viability of bacteria in dental calculus - A microbiological study. Journal of Indian Society of Periodontology, 14(4), 222-226. https://doi.org/10.4103/0972-124X.76921

- Morta, S., Mante, K., Rasa, B., \& Gintaras, J. (2018). The influence of salivary $\mathrm{pH}$ and calcium/phosphate ions concentration on salivary gland stones' formation. Journal of International Medicine and Dentistry, 5(1), 30-38. https://www.lsmuni.lt/cris/handle/20.500.12512/20296

- Mzoughi, Z., Chahdoura, H., Chakroun, Y., Cámara, M., FernándezRuiz, V., Morales, P., Mosbah, H., Flamini, G., Snoussi, M., \& Majdoub, H. (2019). Wild edible Swiss chard leaves (Beta vulgaris L. var. cicla): Nutritional, phytochemical composition and biological activities. Food Research International (Ottawa, Ont.), 119, 612-621. https://doi.org/10.1016/j.foodres.2018.10.039

- Ohtani, M., \& Nishimura, T. (2020). The preventive and therapeutic application of garlic and other plant ingredients in the treatment of periodontal diseases. Experimental and Therapeutic Medicine, 19(2), 1507-1510. https://doi.org/10.3892/etm.2019.8382

- Pápay, Z. E., Kállai-Szabó, N., Ludányi, K., Klebovich, I., \& Antal, I. (2016). Development of oral site-specific pellets containing flavonoid extract with antioxidant activity. European Journal of Pharmaceutical Sciences, 95, 161-169. https://doi.org/10.1016/j. ejps.2016.10.029

- Sacan, O., Orak, H., \& Yanardag, R. (2008). Antioxidant activity of water extract of Eruca sativa Mill. Asian Journal of Chemistry, 20, 3462-3474. https://www.researchgate.net/publication/286940034

- Sacan, O., \& Yanardag, R. (2010). Antioxidant and antiacetylcholinesterase activities of chard (Beta vulgaris L. var. cicla). Food and Chemical Toxicology, 48(5), 1275-1280. https://doi.org/10.1016/j.fct.2010.02.022

- Sarwar Alam, M., Kaur, G., Jabbar, Z., Javed, K., \& Athar, M. (2007). Eruca sativa seeds possess antioxidant activity and exert a protective effect on mercuric chloride induced renal toxicity. Food and Chemical Toxicology, 45(6), 910-920. https://doi.org/10.1016/j. fct.2006.11.013
Selmi Cepis, B., Akyuz, S., \& Yarat, A. (2020). Evaluation of the effect of coffee and carbonated beverages on calcium phosphate precipitation, in the point of formation of calculus. Proceeding 3rd International Eurasian Conference on Biological and Chemical Sciences (EurasianBioChem 2020), (pp. 567-573). Ankara: Turkey www.EurasianBioChem.org. Book.

- Sener, B., \& Kilic, M. (2019). Herbal extracts used in dental disorders. Biomedical Journal of Scientific and Thecnical Research, 19(1) https://www.researchgate.net/publication/334397321_Herbal_ Extracts_Used_in_Dental_Disorders

- $\quad$ Smullen, J., Finney, M., Storey, D. M., \& Foster, H. A. (2012). Prevention of artificial dental plaque formation in vitro by plant extracts. Journal of Applied Microbiology, 113(4), 964-973. https:// doi.org/10.1111/j.1365-2672.2012.05380.x

- $\quad$ Tarasevich, B. J., Chusuei, C. C., \& Alloro, D. L. (2003). Nucleation and growth of calcium phosphate from physiological solutions onto self-assembled templates by a solution formed nucleus mechanism. The Journal of Physical Chemistry B, 107 (38), 1036710377. https://doi.org/10.1021/jp027445p

- Taviano, M. F., Melchini, A., Filocamo, A., Costa, C., Catania, S., Raciti, R., Saha, S., Needs, P., Bisignano, G. G., \& Miceli, N. (2017). Contribution of the glucosinolate fraction to the overall antioxidant potential, cytoprotection against oxidative insult and antimicrobial activity of Eruca sativa Mill. leaves extract. Pharmacognosy Magazine, 13(52), 738-743. https://doi.org/10.4103/pm.pm_245_16

- Taviano, M. F., Filocamo, A., Ragusac, S., Cacciola, F., Dugo, P., Mondelloa, L. Paterniti Mastrazzoa, G., De Rosec, R. F., Celano, M., Lombardo, G. E., Melchinie, A., \& Miceli, N. (2018). Phenolic profile, antioxidant and cytotoxic properties of polar extracts from leaves and flowers of Isatis tinctoria L. (Brassicaceae) growing in Sicily. Plant Biosystems, 152, 795-803. https://doi.org/10.1080/11263504.2017.1338629

- Torki, A., Hosseinabadi, T., Fasihzadeh, S., Sadeghimanesh, A., Wibowo, J. P., \& Lorigooini, Z. (2018). Solubility of calcium oxalate and calcium phosphate crystallization in the presence of crude extract and fractions from Kelussia odoratissima Mozaff. Pharmacognosy Research, 10(4), 379-384.

Tunali, T., Yarat, A., Yanardağ, R., Ozçelik, F., Ozsoy, O., Ergenekon, G., \& Emekli, N. (1999). Effect of parsley (Petroselinum crispum) on the skin of STZ induced diabetic rats. Phytotherapy Research: PTR, 13(2), 138-141. https://doi.org/10.1002/(SICl)10991573(199903)13:2<138 AID-PTR390>3.0.CO;2-X

- $\quad$ Tunali, S., Cimen, E. S., \& Yanardag, R. (2020). The effects of chard on brain damage in valproic acid induced toxicity. Journal of Food Biochemistry, 44(10), XX-XX

https://doi.org/10.1111/jfbc.13382

- Veloz, J. J., Saavedra, N., Alvear, M., Zambrano, T., Barrientos, L., \& Salazar, L. A. (2016). Polyphenol-rich extract from propolis reduces the expression and activity of Streptococcus mutans glucosyltransferases at subinhibitory concentrations. BioMed Research International, 4302706. https://doi.org/10.1155/2016/4302706

- $\quad$ Wang, G., Wang, J. J., Du, L., Fei, L., \& To, S. T. (2016). Inhibitory kinetics and mechanism of flavonoids extracted from Cotinus coggygria Scop. against glioblastoma cancer. Nutrition and Cancer, 68(8), 1357-1368. https://doi.org/10.1080/01635581.2016.1225105

- Weber, M. T., Hannig, M., Pötschke, S., Höhne, F., \& Hannig, C. (2015). Application of plant extracts for the prevention of dental erosion: An in situ/in vitro study. Caries Research, 49(5), 477-487. https://doi.org/10.1159/000431294

- White D. J. (1997). Dental calculus: recent insights into occurrence, formation, prevention, removal and oral health effects of supragingival and subgingival deposits. European Journal of Oral Sciences, 105, 508-522. https://doi.org/10.1111/j.1600-0722.1997.tb00238.x 